\title{
Heavy Metal Pollution of Environment by Mine Tailings and the Potential Reclamation Techniques: A Review
}

\author{
Ashim Sikdar ${ }^{1,2, *} \quad$ Md. Shakhawat Hossain ${ }^{3} \quad$ Shulin Feng ${ }^{4}$ \\ 1.College of Natural Resources and Environment, Northwest A\&F University, Yangling 712100, Shaanxi, China \\ 2.Department of Agroforestry and Environmental Science, Sylhet Agricultural University, Sylhet 3100 , \\ Bangladesh \\ 3.College of Agronomy, Northwest A\&F University, Yangling 712100, Shaanxi, China \\ 4.Institute of Soil and Water Conservation, Northwest A\&F University, Yangling 712100, China
}

\begin{abstract}
Environmental pollution through heavy metal has alarmingly been increased due to industrial and economic development worldwide. Since the industrial revolution started throughout the world, mining activities are being developed, generating huge amount of metal-rich hazardous wastes like tailings and thereby posing potential threat to terrestrial and aquatic ecosystems. The small tailings particles can easily be spread out of the tailings ponds to the surrounding environment because of erosion driven by rain water and strong wind. Subsequently, heavy metals of tailings particles enter into the food chain in different ways and result in serious health issues in humans and animals. Therefore, ecological restoration of mine wastelands is of paramount concern. Different methods for the remediation of mine sites have been developed so far, most of which are expensive and difficult to implement. Countries having severe heavy metal pollution issues are spending huge money every year for the management purpose of these pollution sources and still scientists are doing research to establish eco-friendly, cost-effective, easily-applicable and sustainable remediation strategies for the metal-rich mine tailing sites. This review describes the way of heavy metal contamination of environment by mine tailings, negative effects of heavy metals, research development regarding remediation methods as well as suggests some ideas for the future research direction.

Keywords: Mine tailings, heavy metal contamination, sustainable remediation method, phytoremediation, amendments
\end{abstract}

DOI: $10.7176 / \mathrm{JBAH} / 10-16-05$

Publication date:August $31^{\text {st }} 2020$

\section{Introduction}

In the last few decades, heavy metal (HM) contamination has alarmingly been raised due to industrial and economic development worldwide, posing potential threat to terrestrial and aquatic ecosystems (Kou et al. 2018; Murtaza et al. 2017). Heavy metal load is being escalated in the environment from different anthropogenic sources because of its' non-biodegradable nature ( $\mathrm{Li}$ et al. 2018), thereby causing harm to plants and humans via food chain (Ogbomida et al. 2018). With the rapidly flourishing metal mining industries, mine tailings has been emerged as one of the vital sources of environmental pollution by HMs worldwide (Mugica-Alvarez et al. 2015; Chen et al. 2018). Mining industries compulsorily generate tailings as a by-product, which are composed of sand, water, fine-grained solid material and significant amount of HMs (Santibañez et al. 2012). Mine tailings are often characterized by low organic matter content, poor water holding capacity, sandy texture and high metal concentration and normally, are dumped into open area known as tailings pond without any treatment (Candeias et al. 2015).

More than 10 billion tons of mine tailings are discharged annually in the world (Adiansyah et al. 2015). In USA alone, more than 500,000 abandoned mine sites have been identified; 38,500 of which were belonged to the national forest-lands, these are found to be connected with the destruction of water resources and ecosystems for more than a decade (Salam et al. 2019). About 12,000 tailings ponds are present in different areas of China, occupying a large area of land (Yin et al. 2011). These metal-rich small tailing particles can easily contaminate surrounding soil and water bodies via wind dispersal, surface runoff and leaching, creating disturbance to ecosystem (Sánchez-López et al. 2015). It has been estimated that nearly 10\% of China's agricultural lands are affected by metal contamination (Kou et al. 2018) and around 20 million hectares of farmland are being polluted by toxic metals annually (Cai et al. 2019). At high concentration, HMs often impair the growth of plant root, and cause leaf discoloration and reduced biomass production (Jadia \& Fulekar 2009). Therefore, ecological restoration of mine wastelands is of great concern.

In this review, we discussed on the nature of mine tailings, potential effect on the environment as being a potential source of HM pollution and remediation strategies of such mine wastes, which would provide valuable information for the readers interested in this kind of research direction.

2. General characteristics of mine tailings

Owing to the higher concentration of potentially toxic elements, the trashes and wastes from the mining units are 
considered due be environmentally hazardous (Tordoff et al. 2000). In recent years, the mining activities of different countries gained much concern, since a vast area of land is getting disturbed by mining every year. With no exception, the mines pose severe threat to environment by escalating high levels of toxic elements and and minerals, which further may aggravate the problems with low $\mathrm{pH}$, high electrical conductivity (EC), low in organic matter, low fertility and poor physical properties (Ye et al. 2000). Typically, the pH of mine tailings are around near-neutral, however, the values may be ranged from highly acidic to alkaline (1.6-8.6) according to different environment. In general, EC of the tailings used to be very high approximately $>200 \mathrm{mS} / \mathrm{m}$, this indicates the possible salinity issues. Organic carbon (OC) contents usually low in tailings $(<1 \mathrm{~g} 100 \mathrm{~g}-1)$, however the higher OC if fount may be attributed by the vegetations on the tailing dam. Similarly the total N and total P may ranges $<700 \mathrm{mg} \mathrm{kg}^{-1}$ and 52 to $4400 \mathrm{mg} \mathrm{kg}^{-1}$, respectively; albeit it may differs in different environments (Ye et al. 2002; Conesa et al. 2006; Ma et al. 2006).

The total concentration of metals at any particular tailing doesn't necessarily reflect the bioavailable and potentially mobile fractions (Fergusson 1990); rather it just aids in estimating the associated risk factor thereby emphasizing the attention needed on that site. For estimating the bioavailable metal fraction, the diethylenetriaminepentaacetic acid (DTPA) method is very much beneficent. The DTPA-extractable metal concentration in tailings were reported to be remarkably lesser than total metal concentrations (Ma et al. 2006).

On the basis of mining processing and design of tailing dam, the texture of tailings differs from coarse to fine. As a result of stratification that occurs frequently in the tailing pond, coarser particles will started to settle in the areas near the inlet to tailing dam whereas, the finer materials may settles nearer to the outlets (Hossner \& Hons 1992); which necessitate the crusting and cracking once it is dry. In addition, the extreme high or low water retentions are common in the tailings according to their texture. When the dark colored tailings are subjected to solar radiation, their surface temperatures may raise resulting excessive evapotranspiration and seedling dehydrations. Another major issue of fine tailing particles is the dust particles, since it may drastically contaminate the environment by their easy dispersion through wind and water (Hossner \& Hons 1992). The textures of different tailings range from silty-loam to sandy-loam and sandy, and the physico-chemical properties of the tailings are not suitable for plant growth and development (Ye et al. 2002).

\section{Deleterious effects of heavy metals on human health and plants}

In literature the HMs contamination and their deleterious consequences on ecosystem and several living organisms been widely addressed by many researchers (Manivasagaperumal et al. 2011; Schneider et al. 2016; Kim et al. 2016); for instance their effects on environment, flora, fauna and on human health are the prime research area in current era. In environment, especially in soil it lowers the soil enzymatic activities, affects mineralization and nutrient cycling, reduce the formation of humic substances and soil organic matter thus affecting normal decomposition and material cycling (Ma et al. 2015; Cao et al. 2016). It also causes the land degradation resulting obstruction of normal functioning as well as contaminates and reduce the quality of air, water and soil in closer proximities from HMs source point (Schneider et al. 2016).

It directly influences the pigmentation, biosynthesis, transpiration and battery of antioxidant systems, causes lipid peroxidation which retard the plant growth (Wang et al. 2014; Xian et al. 2015). Besides environmental influences, their integration into the higher animals via soil-crop-food chain digs the attention on HMs management (Cheng et al. 2016). When exposed at higher levels and being carcinogenic agent HMs can cause severe dysfunction in different organs and may ultimately be fatal in higher animals and human beings (Cao et al. 2016).

The specific detrimental impacts of some $\mathrm{HMs}(\mathrm{Zn}, \mathrm{Pb}, \mathrm{Cd}, \mathrm{Cu} \mathrm{Hg}, \mathrm{Cr}$, As, $\mathrm{Ni}$ and $\mathrm{Al}$ ) on human health, plants and environment are described below.

\section{1. $\operatorname{Lead}(\mathrm{Pb})$}

Various human activities such as mining, accelerated production and burning of fossil fuels have resulted the escalation of lead and associated compounds in all the medium such as air, water and soil; also affecting plant, higher animals and human beings through food chain (Nagajyoti et al. 2010). Products such as lead based paints, batteries, cosmetics, bullets, toys, gasoline, plumbing pipes and also other industrial emissions may expose lead into the environment besides HM contaminated soil (Thürmer et al. 2002; Martin \& Griswold 2009). The industries and automobiles in the urban areas contribute a higher amount of $\mathrm{Pb}$ emission (Walraven et al. 2014). Thus $\mathrm{Pb}$ is one of the ubiquitously dispersed in the environment and is reported to be one of the toxic elements that present abundantly in soil; this element is not having any biological functions, not needed by the living system unlike some important micronutrient metal elements such as zinc, copper and manganese. In plants, it causes severe malfunctioning by affects their morphological integrity, growth and photosynthetic processes (Shu et al. 2012); in higher levels it inhibits the seed germination, causes water and mineral nutrient imbalances, alter the enzyme activities and affects membrane permeability (Hassan et al. 2014).

Lead is vicious substance that causes physiological as well as neurological problems to human beings; it enter 
into the system via food or water (Abdelhafez et al. 2014); provided the $\mathrm{Pb}$ was found to be very persistant in aqueous environment (Nagajyoti et al. 2010). The extent of exposures caused different malfunctions; acute exposure lead to hypertension, renal dysfunction, abdominal pain, sleeplessness, fatigue, hallucinations, arthritis, high blood pressure, muscle and joint pain (Odum 2000); whereas, the chronic exposure results in birth defects, psychosis, autism, allergies, weight loss, muscular weakness, kidney damage, brain damage, and may even cause death (Martin \& Griswold, 2009; Abdelhafez et al. 2014).

\subsection{Zinc $(\mathrm{Zn})$}

At a higher concentration, Zn exerts several negative impacts on the living systems. (Lin et al. 2012). In plants, $\mathrm{Zn}$ impacts several metabolic processes since being an essential micronutrient (Cakmak and Marshner 1993). For instant, it involves in the synthesis of various enzymes and proteins, participates in cell division, regulates nucleic acid metabolism (Nadgorska-Socha et al. 2013). The concentration of $\mathrm{Zn}$ in the range of 150-300 $\mu \mathrm{g}$ g-1 of soil is regarded to be toxic, especially to plants (Emamverdian et al. 2015), causing stunted growth, lowering biomass and reduction in crop yield (Soudek et al. 2014). At higher concentrations, it can generate excess ROS (reactive oxygen species) and deficiency of $\mathrm{Fe}$ and $\mathrm{P}$, results in oxidative stress, chlorosis and necrosis, reduction in pigmentation and photosynthesis and ultimately causes membrane disruptions (Tsonev et al. 2012). It also alters the catalytic efficiency of enzyme systems in many plants like pea plants (Romero-Puertas et al. 2004). In humans, it causes malfunctioning of system resulting in hindrance of growth and reproduction; clinical signs includes vomiting, fatigue, dizziness, bloody urine, yellowing of mucus membranes, anemia, diarrhea and multiple organ failures ((Duruibe et al. 2007; Ali et al. 2013).

\subsection{Cadmium $(C d)$}

$\mathrm{Cd}$ is a HM with the specific gravity of about 8.56 times higher than that of water. Cd released into the environment from geogenic origins such as volcanic eruption, weathering and river transport; some of the anthropogenic sources include mining, incineration of municipal wastes, extensive usage of fertilizers, tobacco smoking and as a byproduct during $\mathrm{Zn}$ manufacturing (Wahid et al. 2008). The regulatory limit of cadmium (Cd) in agricultural soil is $100 \mathrm{mg} \mathrm{kg}^{-1}$ soil (Salt et al. 1995).

$\mathrm{Cd}$ when compared to the other $\mathrm{HMs}$ (e.g. $\mathrm{Pb}, \mathrm{Cu}$ ), are highly bioavailable and soluble in soil solutions increasing their phytoavailability and highly leachable by groundwater respectively (Perronnet et al. 2000). Besides, $\mathrm{Cd}$ is often found in plant parts such as grains, vegetables and fruits due to their higher above ground translocation rates (soil to plant transfer) (Satarug et al. 2010). The plants grown in highly polluted soil shows the symptoms of visible leaf chlorosis, browning of leaf and root tips, leaf roll and damage in PS-I, PS-II photosystems, growth inhibition and further to necrosis and plant death (Guo et al. 2008; Daud et al. 2013). Being a highly toxic and non-essential HM, it causes adverse effects on plant enzymatic systems, initiates oxidative stress and also causes nutritional deficiency in the plant systems (Irfan et al. 2013).

The international agency for research and cancer classified cadmium and related compounds under Group I carcinogenic agents to human beings (Henson \& Chedrese 2004). Inhalation and ingestion is the major exposure pathway to human beings; upon degree of exposure it may results in acute or chronic conditions (Chakraborty et al. 2013). Generally the Cd exposure causes vomiting, nausea, abdominal cramps and diarrhea, muscular weakness and dizziness followed by convulsions, shock and unconsciousness; whereas in higher concentrations, it causes pulmonary emphysema, skeletal damage (osteoporosis), kidney damage, lung cancer and prostate cancer (Li et al. 2014). In addition, the women exposed high during pregnancy results in premature birth and reduced birth weights (Henson \& Chedrese 2004).

\subsection{Copper $(\mathrm{Cu})$}

Copper has been regarded as a salient pollutant of the air and agricultural soils; rigorous usage of fungicides, pesticides, herbicides, organic sludges and manure applications escalates the concentration of $\mathrm{Cu}$ in agricultural soils (Panou-Filotheou et al. 2001). Besides intensified industrialization, smelting and mining activities significantly increased the levels of $\mathrm{Cu}$ in ecosystems. $\mathrm{Cu}$ is the essential micronutrient for plant that plays impeccable role in cell wall metabolism, CO2 assimilation and ATP synthesis (Goswami et al. 2016). An excessive amount of $\mathrm{Cu}$ in soil is cytotoxic to plants posing severe stress and engenders plant injury. $\mathrm{Cu}$ toxicity fosters a remarked reduction in plants' root volume obstructing water, mineral and nutrient uptake which may lead to chlorosis, necrosis and growth retardation (Singh et al. 2007). It also generates the excessive ROS that leads to oxidative stress which disturbs the metabolic pathway and damages to macromolecules (Goswami et al. 2016).

In contrast, primarily the $\mathrm{Cu}$ is exposed to the human beings through the consumption of $\mathrm{Cu}$-laden food and water. Excessive intake may results in mucosal irritation and corrosion, capillary damages, hypo-chromic anemia, osteoporosis, gastrointestinal irritation, hepatic and renal damage (USEPA 2002). 


\section{5. $\operatorname{Mercury}(\mathrm{Hg})$}

Mercury is highly toxic HM that released into the environment through various industrial activities such as pharmaceuticals, paper and pulp preservatives, agro-industry, coal and metallurgy, metal refineries, chlorine and caustic soda productions (Morais et al. 2012; Chen et al. 2012). In addition, Hg is extensively employed commercially for making fluorescent bulbs, thermometers, electronic switches and other products (Shanley et al. 2002). Hg has the capability of amalgamating with other elements and takes various organic and inorganic forms; out of which its organic form is predicted to be highly poisonous (Hosseini et al. 2013).

The ionic form of mercury $\left(\mathrm{Hg}^{2+}\right)$ mostly prevails in agricultural soil and can easily accumulate in different plants (Wang and Greger 2004; Israr et al. 2006). For instance, $\mathrm{Hg}^{2+}$ can readily bind to water channel proteins, thus exerts closure of leaf stomata resulting barrier in water flow within plant parts (Zhang and Tyerman 1999). At high levels, it also obstruct mitochondrial functioning, triggers ROS generation and oxidative stress that leads to disruption of membrane lipids as well as affects normal cellular metabolisms (Israr et al. 2006). In humans, the exposure to high levels of mercury can cause harm to the brain, kidneys and the developing fetus (Alina et al. 2012). Organic $\mathrm{Hg}$ exposure significantly contributed by consuming fishes and aquatic animals. The common symptoms of organic $\mathrm{Hg}$ poisoning are headache, memory problems, fatigue, tremors and hair loss (Ainza et al. 2010).

\subsection{Chromium (Cr)}

Chromium exists in different oxidation states, but the trivalent $\left(\mathrm{Cr}^{3+}\right)$ and hexavalent $\left(\mathrm{Cr}^{6+}\right)$ are the most toxic forms to animals, humans and plants (Monalisa \& Kumar 2013). Many industries widely employed chromium in their productions and manufacturing; mainly electroplating, metallurgy, production of paints and pigments, wood preservation, tanning, pulp and paper production (Ghani 2011).

Environmental Protection Agency (EPA), International Agency for Research on Cancer (IARC) and World Health Organization (WHO) classified chromium, especially $\mathrm{Cr}$ (VI) as a human carcinogenic agent (Shaffer et al. 2001; Jeyasingh \& Philip 2005; Huang 2009). Inorganic forms of mercury cause congenital malformation, spontaneous abortion and gastrointestinal disorders. Whereas organic forms like monomethyl and dimenthyl mecury may cause acrodynia, stomatitis, gingivitis, neurological disorders, total damage to the brain (Duruibe et al. 2007).

In plants, $\mathrm{Cr}$ causes inhibition in growth, chlorosis, wilting of leaf tops, root injury as well as nutrient imbalances (Ghani 2011); in general, its toxicity induces alterations in the germination process affecting growth retardation in different plant parts (roots, stems and leaves). Consequently, it reduces the total dry matter production of plant thereby affecting total yield (Shanker et al. 2005). Moreover, $\mathrm{Cr}$ also interferes plants' physiological functioning such as photosynthesis, water retention and affects mineral nutrition. It is been documented that the $\mathrm{Cr}$ may alters the metabolism through its direct influence on enzymes or metabolites as well as generation of ROS (Adrees et al. 2015).

\subsection{Arsenic (As)}

Arsenic is released into the ecosystem mainly due to the anthropogenic activities such as mining and ore processing (Matschullat 2000). The As toxicity in plants lead to the reduction of seed germination, retardation of plant growth, associated reductions in height, leaf area, tiller and panicle, dry matter, leaf chlorosis, reduction in yield as well as wilting of plant (Chibuike et al. 2014).

The inorganic forms of arsenic (arsenite and arsenate) are very much hazardous to human health; are carcinogenic substances causing different types of cancers such as lungs, liver, bladder and skin (Abdelhafez et al. 2014). More than 30 countries round the globe documented the major cause for the arsenic poisoning as contaminated drinking water (Chowdhury et al. 2000). WHO specified the limits of arsenic level in ground water as $10 \mu \mathrm{L} \mathrm{L}^{-1}$; if any drinking water sources that are having 10-100 times higher than the specified value can be consider as a severe threat to human health (Hoque et al. 2011). Based on the exposure, the arsenic toxicity may be either acute or chronic; the chronic toxicity normally termed as arsenicosis (Mazumder 2008; Li et al. 2014).

\subsection{Nickle (Ni)}

The anthropogenic activities such as smelting, mining, burning of oil and coal, application of phosphate fertilizers and pesticides introduces the $\mathrm{Ni}^{2+}$ in environment (Gimeno-García et al. 1996). Elevated concentrations of $\mathrm{Ni}^{2+}$ in soil may directly results in alteration of various physiological functioning in plant grown on that area; toxicity symptoms includes chlorosis, necrosis, impairment of nutrient balance and disrupts the membrane integrity in different plant species (Rahman et al. 2005; Ma et al. 2009). Generally the plants suffering from $\mathrm{Ni}^{2+}$ toxicity is indicated by the reduced uptake of water (Gajewska et al. 2006). The Ni toxicity in higher animals and humans resulted in various deformities such as inhibition of spermatogenesis, amylase enzymes, insulin production and kidney functioning (Ali et al. 2013). The nickel carbonyl $\mathrm{Ni}(\mathrm{Co})_{4}$ is the most menacing forms of $\mathrm{Ni}$; are generated during cigarette smoking which may lead to severe pulmonary fibrosis (respiration disorders) and renal 
malfunctioning (Srivastava and Gupta 1996).

\subsection{Aluminum (Al)}

$\mathrm{Al}$ is escalated in the environment during their mining processes (Gupta et al. 2013). It is reported to be highly toxic in acidic environment especially below 5-5.5, since increased bioavailabilty of $\mathrm{Al}+3$. The soil surface with the lowered $\mathrm{pH}$ due to $\mathrm{Al}+3$ toxicity is of great concern as it directly impacts the crop production (Emamverdian et al. 2015). Its interaction with plasma membrane and apoplastic, symplastic targets may affects the normal physiological and cellular functioning of plants. The common effects are root growth inhibition, cellular modification in leaves, leaf discoloration and death of leaves, and leaf necrosis (Gupta et al. 2013).

Dermal contact, inhalation and ingestion are the major routes of $\mathrm{Al}$ exposure in human beings. The $\mathrm{Al}$ contaminated drinking water, food, beverages, and certain drugs took important part in introducing Al to the human body. Symptoms like mouth and skin ulcers, nausea, rashes in the body, vomiting and diarrhea are due to the $\mathrm{Al}$ toxicity in humans; the symptoms are however only lasts for a short period and are mild (Clayton 1989). Nevertheless, WHO hypothesized the risk factor of Alzheimer disease (AD) will be increased if humans are constantly exposing to $\mathrm{Al}$ (WHO 1997); since Al causes adverse effects on central nervous system, problems with memory and balancing as well as loss of motor coordination (Krewski et al. 2007).

Due to the above mentioned adverse effects of different HMs on plants and human health, it is imperative adopt a safe and economically efficient remediation technologies for the remediation of HM polluted sites. Plant based technology assisted by soil amendments are considered as a potentially safe, green and economical technology. This technology is termed as phytoremediation, which is environment friendly, solar driven, nondestructive, non-invasive, clean and aesthetically pleasant (Singh et al. 2012; Yildirim et al. 2017).

\section{Remediation technologies of heavy metal contaminated mine sites}

Industrialization and urbanization led to the increase in the mining activities in order to meet out the market demand; continuous production as well as the exploitation of natural resources left behind escalation of metal content in the environment. Continuous mining have resulted in the conversion of vast sum of land into useless unproductive and barren sites round the globe. The prime motive of remediation of these sites is to reduce the risk of toxic metal contamination to the adjacent environment. The remediation technologies are mainly categorized into physical remediation, chemical remediation and biological remediation (Wang et al. 2017); mainly these categorization done on the basis of (i) the nature of action that is applied on the metal immobilization or extraction; (ii) the location where the process is applied (in-situ or ex-situ); and (iii) technology type (Dermont et al. 2008).

Physical treatments include excavation, land-filling, soil replacement, washing or solidification and thermal desorption. Traditionally on-site management or excavation used to clean up the polluted site, but such approach will only shift the problem to the other places and also additionally results in secondary pollution due to the transportation and containment on other sites (Thakur et al. 2016). In order to partly reclaim the soil or to dilute the metal content, soil replacement technique is helpful (Zhang et al. 2004). Soil washing ensures the elimination of metal content but it is inevitable to avoid the pollutant rich residues as a byproduct, and moreover the soil may become unsuitable for establishing vegetation (Tangahu et al. 2011). On the basis of pollutants' volatile nature, the contaminated soil were subject the thermal treatments by microwave, steam and infrared radiations in order to let the pollutant volatile (e.g. Hg, As) is called thermal desorption; the pollutant thus removed are retrieved by carrier gas or creating vacuum pressure ( $\mathrm{Li}$ et al. 2010). But this is not popular since it needs expensive devices and desorption time consumption which limits their application in soil metal remediation (Aresta et al. 2008).

Chemical remediation methods involve chemical leaching, Chemical fixation, Electrokinetic remediation, Vitrify technology etc. washing out the contaminants from the soil using various solutions such as fresh water, reagent, other fluids or also chemical gases are called chemical leaching (Tampouris et al. 2001; Ou-Yang et al. 2010). The HMs bound in the soil substrate is transferred to the liquid phase by ions exchange, precipitation, adsorption and chelation during the soil chemical washing, further can be recovered from leachate. The chemical fixation used to fix/immobilize the soil metal contaminant through the addition of reagent which makes them less soluble, immovable, low toxic substances and eventually decreases their mobility in water or other environmental media as well as translocation to plants (Zhou et al. 2004). Whereas, in electrokinetic remediation, particular voltage is applied at the two ends of soil in order to form electric gradient, so that the pollutants will be carried towards two pole via electrophoresis, electric osmosis or electric migration (Fan et al. 2010). Another technique called vitrify technique wherein the polluted soil is subjected to heating at high temperatures $1400 \sim 2000^{\circ} \mathrm{C}$, during which the organic compounds will be decomposed or volatilized and the steam produced as well as pyrolysed products will be collected by off-gas treatment systems; once after losing the temperature the products forms rock shape vitreous sieges bounding the immobilized metals.

Altogether, physical and chemical remediation methods have many limitations including; irreversible alteration in soil properties, alterations in soil microflora, secondary pollutions as well as these methods are generally expensive and need intensive labour, which make them a inappropriate solution to solve this problem 
(Zubair et al. 2016; Jegatheesan et al. 2016). In contrast, the biological remediation is appropriate, cost-effective and needs less management; it includes microbial remediation, animal remediation and phytoremediation. Generally the microorganisms cannot directly degrade HMs, but it influences their migration and transformation by altering physiochemical status; the main mechanism includes precipitation, complexation, oxidation/reduction, extracellular complexation and intracellular accumulation. Besides, microbial leaching is very efficient technique for extracting valuable metals from low-grade ores and mineral concentrates; however, their efficiency mainly influenced by various factors such as $\mathrm{pH}$, moisture content, temperatures and oxygen levels, and sometime their selective interactions with some contaminants may incur secondary pollution to the environment as well.

Animal remediation is based on the characterization of some lower animals that has the capacity to adsorb, degrade or to migrate HMs in order to reduce or remove the toxicity levels to the environment. For instance, the earthworms are efficiently utilized for reclaiming the HM polluted soil. Kou et al. (2008) reported that the efficiency of $\mathrm{Pb}$ accumulation by earthworm when testing earthworm on $\mathrm{Pb}$ contaminated sites; also acknowledged the accumulation rate was found to be increasing with the increased $\mathrm{Pb}$ concentration in soils.

The recruitment of living plants in fixing or adsorbing metal contaminates in order to clean up the environment is termed as phytoremediation. When compared to their physical and chemical counterparts, phytoremediation offer an efficient, environmental friendly and cost-effective technique. Since last three decades, it gained public attention and other regulatory support in soil reclamation. These techniques are broadly divided into three such as phytostabilization, phytovolatilization and phytoextraction (Glick 2010).

Phytostabilization referred to the fixing of metal pollutant by plants via adsorption, oxidation/reduction and precipitation, thus reducing their bioavailability and migration into food chain and water table (Wang et al. 2009). Whereas, in phytoextraction, the metal tolerant/ hyper accumulator plants adsorb, translocates and further process the HM contaminants in the above ground plant part. Naturally, scientists consider phytostabilization more suitable and practical than other phytoremediation techniques for its long-term service as vegetation coverage (Mendez et al. 2007).

It was estimated that the remediation of tailings using conventional techniques such as chemical stabilization, capping and excavation are very expensive and costs almost 130,000 to 1,600,000 \$US ha-1 (Berti and Cunningham 2000). Hence, the phytoremediation takes up the place with the recognition of its potential as well as they are less expensive when compared to the conventional techniques; in general it costs about 60,000 to 300,000 \$US ha ${ }^{-1}$ and also stood as minimal environmental damages (Kidd et al. 2009).

\section{Importance of phytostabilization in mine tailings}

Phytostabilization creates a vegetative cap for the long-term stabilization and containment of the tailings. The plant stabilizes the metal contaminants by various means in various plant parts; for instance, the canopy reduces aeolian dispersal and the roots apart from preventing through water erosion, it stabilizes metals either by adsorption and accumulation or restraining in rhizospere by precipitation and complexation. Over and above, the establishment of plants in tailing areas intensifies the heterotrophic microbial community composition assisting plant growth and metal stabilization (Glick 2003; Mendez et al. 2007). The phytostabilization focuses on sequestration of metal contaminants within rhizosphere boundaries thus restricting their translocation to plant parts in contrast to phytoextraction (Ernst 2005). Further it makes the metal contaminants to be less bioavailable to the higher animals and human beings marking its significant in food chain; preventing biomagnification (Wong 2003). Since mine tailings are not suitable for growing plants due to having several adverse features, addition of organic or inorganic amendments in phytostabilization process is very common to immobilize metals in situ as well as to improve soil health for facilitating plant growth and survival and such assisted phytostabilization approach often referred to aided phytostabilization (Mench et al. 2006; Vangronsveld et al. 2009). Selection of appropriate plant species is the major issue to make any phytostabilization process successful. As reported in the previous studies, plant species that are deep rooted, capable to produce high biomass, tolerant to high concentrations of metals, translocate less metals from roots to above-ground parts and able to adapt with poor soil nutrient found to be suitable for phtostabilization (Pulford \& Watson 2003). Aided phytostabilization, besides employing plants alone, the application beneficial amendment in order to enhance the phytostabilization practices is very useful strategy to deal with the mine tailing reclamations (Lee et al. 2014).

Additionally, these strategies can help in stabilizing the environment by two means; 1) the added amendments alter the physicochemical status of metal contaminants by various means of adsorption/ absorbtion, complexation and speciation in a way to prevent their bioavailability, 2) the established vegetation may improve soil physicochemical and biological parameters in order to restore normal soil functioning of metal-polluted areas in the long term (Bolan et al. 2011) and with progression of time may convert tailings materials into soil (Mendez \& Maier 2008). Aided phytostabilization also confer the containment of metal contaminants within the vadose zone by complexation and precipitation within rhizospere or accumulating in roots thus preventing te mobilization of HMs via wind, soil dispersion, leaching and water erosion (Bolan et al. 2011). Selection of native plants for phytostabilization practices are very much appropriate as the plants can ensure their growth establishments since 
they have evolved survival mechanisms that fits to that particular environment; secondly by avoiding non native plant species will further helps in avoiding the establishment of potentially invasive species that may affect local plant diversity. Selection of a plant variety for revegetation is the key factor in phytostabiliztion; various perennial grasses, shrubs, and trees are preferable. The grasses may give a quick cover to the ground and limits the aeolian dispersal within the due time taken for establishment by shrubs and trees (Williams \& Currey 2002); contrarily, the shrubs and trees can strengthen the remediation by establishing stronger root system that prevent erosion and extensive dense canopy cover to prevent dispersal by air over the long term. Hence, recruiting these plants and establishing on mine waste along with aided amendments can help in achieving the phytostabilization through various means of complexatioon, precipitation, sorption and accumulation in root tissues (Mendez \& Maier 2008; Mirza et al. 2011). Moreover, usage of woody plants permits soil structure development besides offering thick vegetation cover and erosion control; it also minimizes the leaching and efficient utilization of ground water and nutrients (Zhang et al. 2011). Normally, the tailings are poor in organic matter and nutrient levels to support vegetation, but through the assisted phytostablization, organic matter can be introduced by various amendments such as plant residues, compost, biochar, animal manure, municipal waste, peat, woodchips, sawdust and other industrial residues (Li \& Huang 2015); which may also improve soil structure, water holding capacity, nutrient content and cation exchange capacity.

\section{Use of different amendments to facilitate phytostabilization of mine tailings}

Normally, the mine tailing are characterized as unfavorable environment for plant establishments due to their extreme physicochemical conditions such as extreme $\mathrm{pH}$, high salinity, poor water retention capacity, high concentrations of HMs, and less soil organic matter and often infertile (Asensio et al. 2013a). In order to establish plant growth in such poor environment, it is always needed to improve the physicochemical characteristics by amending various organic and inorganic additives (Courtney et al. 2009), which may also serves as an attempt in soil amelioration.

Various organic amendments have been already employed in reclamation of tailings includes composts (kitchen wastes, garden waste, olive mill waste, animal wastes, spent mushroom), biosolids (sewage sludge, sanitary wastes, food wastes), manures (goat, cattle, pig, poultry), biochars (crop straw, hardwood, tea waste, fruit waste), slurry (pig, cattle) and peat (Park et al. 2011; Bolan et al. 2014; Karna et al. 2017). These amendments can be used alone or in combination with the other amendments of same/different sources (Bolan et al. 2014) and/ or sometimes added along with other inorganic materials (especially of alkaline) such as lime stones, marble waste, hydrated lime, red mud and phosphate fertilizers (Pardo et al. 2014, 2016; Karna et al. 2017). The addition of lime in order to neutralize/ reduce the toxicity of metals is a generally adopted method in reclaiming oxidized mine tailings (Catalan et al. 2002); however, the main limitation of liming amendments are their dissolution and leaching phenomenon in some strong acidic environments (Ruttens et al. 2010). Moreno et al. (2004) documented the use of pumice as inorganic amendment to improve the drainage of fine-grained tailings. Also, the use of phosphatebased materials is reported to be useful in immobilizing HMs in soil (McGowen et al. 2001).

The rate of addition of inorganic fertilizers are of important concern in case of selecting a native vegetation for phytostabilization practices of tailings in arid and semi arid environments, since the vegetations are already accustomed to establish its growth under low nutrient condition, so excessive fertilizer input may tend to change the plants to respond differently (Piha et al. 1995). Phosphate fertilizers are exceptional, which is utmost important to alleviate the phosphorous shortage caused by the formation of insoluble metal-phosphates; albeit, the addition of phosphate may sometime increase the arsenic uptake by plants and leaching of mine tailings since their chemical similarities with arsenate (Mains et al. 2006).

Altogether, the inorganic additives basically improve few of the physical properties of tailing such as $\mathrm{pH}$, decreases metal solubility, few chemical behaviors and drainage (Janoš et al. 2010). Whereas, comparatively the organic amendments proven to improve various soil properties, nutritional levels, water retention capacity along with buffering the $\mathrm{pH}$ levels and indirectly affecting the mobility of metals by adsorption and complexation (Tordoff et al. 2000).

Recruiting compost as an amendment in phytoremediation trails of mine tailings at Iron King Mine and Humboldt Smelter Superfund sites were studied (Gil-Loaiza et al. (2016); results showed at about 41 months 21 to $61 \%$ canopy was established in compost amended treatment and there were no plant establishment was reported in unamended tailing soils. As previous study documented, compost amendment and seeding facilitated plant growth and development in preliminary greenhouse studies, and afterwards sustained growth over 4 years suggested feasibility for this phytostabilization technology in the field trial (Gil-Loaiza et al. 2016). The biosolids from sludges were used as an amendment for $\mathrm{Cu}$ tailings by Asensio et al. (2013b) who observed the significant improvements in the biological quality of the soil as well as biological community structures. Another report documented that the application of class A biosolids on the mine tailings increases bacterial growth (Pepper et al. 2012).

Biochar, an organic amendment is recently gaining attention for reclamation of polluted environment by 
efficient means of immobilization of various contaminants (HMs, organic pollutants) (Ahmad et al. 2016). It also improves soil nutrition, soil texture and physiological properties such as $\mathrm{pH}, \mathrm{EC}, \mathrm{CEC}$ and water holding capacity (Fellet et al. 2011). Biochar also employed in phytostabilization practices with an aim of stabilizing the toxic metals by limiting their mobility and bioavailabilities as well as improving the vegetation cover by supporting soil nutrition.

The Agricultural wastes (such as crop stalks and animal manure) contain different functional groups such as carboxyl and hydroxyl groups which serve as the suitable sites for metal adsorption (Liu 2017). In addition, addition of organic materials like woodchips, pulp waste, and cattle manure on tailings shows positive effects for the treatment of acid mine drainage (Baker et al. 2011; Hulshof et al. 2006). Along with low cost and renewable nature, they increase microbial quantity and activity (Seaker and Sopper, 1988).

In addition, many studies reported the positive effects of organic additives (municipal waste, manure compost, biosolid compost and poultry litter) in reducing the toxicity of HM on soil enzymes (Karaca et al. 2006; Xian et al. 2015). Organic amendments may enhance soil enzymatic activity in many of the ways; (1) intra and extracellular enzymes stimulate microbial activity in the added materials, (2) some of the functional groups of humic acid such as carboxyl, phenolic, alcohol, and carbonyl groups may react with the ions to form metal-humate complexes (metal chelation) in order to stabilize them (Pascual et al. 1998). Ameloot et al. (2013) reported the increment of dehydrogenase activity $(73 \%)$ after adding biochar produced at $350^{\circ} \mathrm{C}$. Jain et al. (2016) also has documented the improved phophatase enzyme activity of mine spoils after amending organic amendments. Kizilkaya et al. (2004) reported that addition of organic matter in treatments increases the CAT activity when compared to the control soil; also suggested a minimum quantity of organic matter is necessary for enzyme activity and the activity increases directly with the increasing rate of organic amendment.

\section{Conclusion}

Modern civilization is greatly depends on non-ferrous metals because of their intensive usage in manufacturing processses. Hence, inspite of having serious detrimental impacts on environment and human health, it seems to be impossible to stop or reduce the activity of mining industries and thereby generation of hazardous mine wastes like tailings. In this situation, to develop proper management techniques for decontaminationg the mine tailings so that we can reduce the harmful effects to the minimum level. As reported, the existing physical and chemical technologies are mostly expensive, often involve in secondary pollution and thus, not feasible specially for large mine wastelands. Recently, scientists suggested phytoremediation as the most feasible practice to remediate mine tailings having high metal load, by which environmental risks associated with such mine wastes can be attenuated as well as creation of aesthetically unpleasant conditions can be avoided. Due to having HMs in high concentrations and poor soil quality, mine tailings are not unfit for growing plants. Therefore, screening out of tolerant native plant species for any particular mine site is the primary challenge. Moreover, considering the need of long-term vegetation coverage on mine sites, phytostabilization attracts the attention of the scientists over phytoextraction. With the development of scientific ideas, aided-phytostabilization is being greatly popularized, where the used amendments help vegetation establishment by decreasing the phytoavailable metal concentrations as well as improving soil quality. Although metal removal or stabilization is the primary goal of any kind of phytoremediation, the success of the process mainly depends on the improvement of plant antioxidant enzymes to enhance plant tolerance and construction of soil functional ability. However, instead of a single method like phytoextraction or immobilizing agents, combined use of several techniques like phytostabilization, amendments and microorganisms might be of more useful. Experiments are necessary to evaluate avilable bio-waste materials and plant species to facilitate the restoration of mine-spoils having various properties. The research attempts could be extended to molecular studies to find the mechanism of HMs phytostabilization, immobilization and factors governing the translocation in the soil-plant system. Most importantly, long-term field level investigations are needed to evaluate the results of lab and green-house experiments.

\section{Declaration of Competing Interest}

The authors declare that they have no known competing financial interests or personal relationships that could have appeared to influence the work reported in this paper.

\section{Acknowledgments}

Authors are thankful to the Department of Agroforestry and Environmental Science, Sylhet Agricultural University, Sylhet 3100, Bangladesh. They also thank Dr. Tanveer Ali Sial for his constructive suggestions to improve the quality of the manuscript.

\section{References}

Abdelhafez, A.A., Li, J., Abbas, M.H. (2014). Feasibility of biochar manufactured from organic wastes on the stabilization of heavy metals in a metal smelter contaminated soil. Chemosphere, 117, 66-71. 
doi:10.1016/j.chemosphere.2014.05.086.

Adiansyah, J.S., Rosano, M., Vink, S., Keir, G. (2015). A framework for a sustainable approach to mine tailings management: disposal strategies. Journal of cleaner production, 108, 1050-1062.

Adrees, M., Ali, S., Iqbal, M., Aslam Bharwana, S., Siddiqi, Z., Farid, M., Ali, Q., Saeed, R., Rizwan, M. (2015). Mannitol alleviates chromium toxicity in wheat plants in relation to growth, yield, stimulation of antioxidative enzymes, oxidative stress and $\mathrm{Cr}$ uptake in sand and soil media. Ecotoxicology Environmental Safety, 122, 1-8. doi:10.1016/j.ecoenv.2015.07.003.

Ahmad, M., Ok, Y.S., Rajapaksha, A.U., Lim, J.E., Kim, B.Y., Ahn, J.H., Lee, Y.H., Al-Wabel, M.I., Lee, S.E., Lee, S.S. (2016). Lead and copper immobilization in a shooting range soil using soybean stover-and pine needle-derived biochars: Chemical, microbial and spectroscopic assessments. Journal of Hazardous Materials, 301, 179-186.

Ainza, C., Trevors, J., Saier, M. (2010). Environmental mercury rising. Water, Air, and Soil Pollution, 205, 47-48.

Ali, H., Khan, E., Sajad, M.A. (2013). Phytoremediation of heavy metals - Concepts and applications. Chemosphere, 91, 869-881. doi:https://doi.org/10.1016/j.chemosphere.2013.01.075.

Alina, M., Azrina, A., Mohd Yunus, A., Mohd Zakiuddin, S., Mohd Izuan Effendi, H., Muhammad Rizal, R. (2012). Heavy metals (mercury, arsenic, cadmium, plumbum) in selected marine fish and shellfish along the Straits of Malacca. International Food Research Journal, 19.

Ameloot, N., De Neve, S., Jegajeevagan, K., Yildiz, G., Buchan, D., Funkuin, Y.N., Prins, W., Bouckaert, L., Sleutel, S. (2013). Short-term CO2 and N2O emissions and microbial properties of biochar amended sandy loam soils. Soil Biology and Biochemistry, 57, 401-410. doi:https://doi.org/10.1016/j.soilbio.2012.10.025.

Aresta, M., Dibenedetto, A., Fragale, C., Giannoccaro, P., Pastore, C., Zammiello, D., Ferragina, C. (2008). Thermal desorption of polychlorobiphenyls from contaminated soils and their hydrodechlorination using Pdand Rh-supported catalysts. Chemosphere, 70, 1052-1058. doi:10.1016/j.chemosphere.2007.07.074.

Arif, M.S., Riaz, M., Shahzad, S.M., Yasmeen, T., Ashraf, M., Siddique, M., Mubarik, M.S., Bragazza, L., Buttler, A. (2018). Fresh and composted industrial sludge restore soil functions in surface soil of degraded agricultural land. Science of the Total Environment, 619, 517-527, doi:10.1016/j.scitotenv.2017.11.143.

Asensio, V., Covelo, E.F., Kandeler, E. (2013b). Soil management of copper mine tailing soils-sludge amendment and tree vegetation could improve biological soil quality. Science of the total environment, 456, 82-90.

Asensio, V., Vega, F.A., Singh, B.R., Covelo, E.F. (2013a). Effects of tree vegetation and waste amendments on the fractionation of $\mathrm{Cr}, \mathrm{Cu}, \mathrm{Ni}, \mathrm{Pb}$ and $\mathrm{Zn}$ in polluted mine soils. Science of the Total Environment, 443, 446453.

Baker, L.R., White, P.M., Pierzynski, G.M. (2011). Changes in microbial properties after manure, lime, and bentonite application to a heavy metal-contaminated mine waste. Applied soil ecology, 48, 1-10.

Barrutia, O., Artetxe, U., Hernández, A., Olano, J.M., García-Plazaola, J.I., Garbisu, C., Becerril, J.M. (2011). Native Plant Communities in an Abandoned $\mathrm{Pb}-\mathrm{Zn}$ Mining Area of Northern Spain: Implications for Phytoremediation and Germplasm Preservation. International Journal of Phytoremediation, 13, 256-270.

Berti, W.W.R.; Cunningham S.D. Phytostabilization of metals. In: Raskin I, Ensley BD (eds) Phytoremediation of toxic metals - using plants to clean up the environment. John Wiley \& Sons, Inc., New York. 2000, 71-88.

Bolan, N., Kunhikrishnan, A., Thangarajan, R., Kumpiene, J., Park, J., Makino, T., Kirkham, M.B., Scheckel, K. (2014). Remediation of heavy metal (loid) s contaminated soils-to mobilize or to immobilize? Journal of Hazardous Materials, 266, 141-166.

Bolan, N.S.; Park, J.H.; Robinson, B.; Naidu, R.; Huh, K.Y. Phytostabilization: a green approach to contaminant containment. In Advances in agronomy, Elsevier: 2011; Vol. 112, pp. 145-204.

Cai, L.M., Wang, Q.S., Luo, J., Chen, L.G., Zhu, R.L., Wang, S., Tang, C.H. (2019). Heavy metal contamination and health risk assessment for children near a large $\mathrm{Cu}$-smelter in central China. Science of The Total Environment, 650, 725-733. doi:https://doi.org/10.1016/j.scitotenv.2018.09.081.

Cakmak, I., Marshner, H. (1993). Effect of zinc nutritional status on superoxide radical and hydrogen peroxide scavenging enzymes in bean leaves. Plant nutrition-from genetic engineering field practice. Kluwer, The Netherlanads, 133-137.

Candeias, C., Ávila, P.F., da Silva, E.F., Ferreira, A., Durães, N., Teixeira, J.P. (2015). Water-Rock Interaction and Geochemical Processes in Surface Waters Influenced by Tailings Impoundments: Impact and Threats to the Ecosystems and Human Health in Rural Communities (Panasqueira Mine, Central Portugal). Water, Air, \& Soil Pollution, 226, 23. doi:10.1007/s11270-014-2255-8.

Cao, S., Wang, W., Wang, F., Zhang, J., Wang, Z., Yang, S., Xue, Q. (2016). Drought-tolerant Streptomyces pactum Act12 assist phytoremediation of cadmium-contaminated soil by Amaranthus hypochondriacus: great potential application in arid/semi-arid areas. Environmental science and pollution research international, 23, 14898-14907. doi:10.1007/s11356-016-6636-y.

Catalan, L.J., Buset, K.C., Yin, G. (2002). Reactivity of oxidized sulfidic mine tailings during lime treatment. 
Environmental science \& technology, 36, 2766-2771.

Chakraborty, S., Dutta, A.R., Sural, S., Gupta, D., Sen, S. (2013). Ailing bones and failing kidneys: a case of chronic cadmium toxicity. Annals of clinical biochemistry, 50, 492-495.

Chen, C.W., Chen, C.F., Dong, C.D. (2012). Distribution and Accumulation of Mercury in Sediments of Kaohsiung River Mouth, Taiwan. Apcbee Procedia, 1, 153-158.

Chen, J., Liu, Y.Q., Yan, X.W., Wei, G.H., Zhang, J.H., Fang, L.C. (2018). Rhizobium inoculation enhances copper tolerance by affecting copper uptake and regulating the ascorbate-glutathione cycle and phytochelatin biosynthesis-related gene expression in Medicago sativa seedlings. Ecotoxicology and Environmental Safety, $162,312-323$

Cheng, J., Qiu, H., Chang, Z., Jiang, Z., Yin, W. (2016). The effect of cadmium on the growth and antioxidant response for freshwater algae Chlorella vulgaris. SpringerPlus, 5, 1290-1290. doi:10.1186/s40064-016-29631.

Chibuike, G.U., Obiora, S.C. (2014). Heavy metal polluted soils: effect on plants and bioremediation methods. Applied and environmental soil science, 2014.

Chowdhury, U.K., Biswas, B.K., Chowdhury, T.R., Samanta, G., Mandal, B.K., Basu, G.C., Chanda, C.R., Lodh, D., Saha, K.C., Mukherjee, S.K. (2000). Groundwater arsenic contamination in Bangladesh and West Bengal, India. Environ Health Perspect, 108, 393-397. doi:10.1289/ehp.00108393.

Clayton, B. Water Pollution at Lowermoor, North Cornwall: Report of Cornwalll health authority: 1989.

Conesa, H.M., Faz, Á., Arnaldos, R. (2006). Heavy metal accumulation and tolerance in plants from mine tailings of the semiarid Cartagena-La Unión mining district (SE Spain). Science of the total environment, 366, 1-11.

Courtney, R., Jordan, S., Harrington, T. (2009). Physico-chemical changes in bauxite residue following application of spent mushroom compost and gypsum. Land Degradation \& Development, 20, 572-581.

Daud, M.K., Ali, S., Variath, M.T., Zhu, S.J. (2013). Differential physiological, ultramorphological and metabolic responses of cotton cultivars under cadmium stress. Chemosphere, 93, 2593-2602. doi:https://doi.org/10.1016/j.chemosphere.2013.09.082.

Dermont, G., Bergeron, M., Mercier, G., Richer-Laflèche, M. (2008). Metal-contaminated soils: remediation practices and treatment technologies. Practice periodical of hazardous, toxic, and radioactive waste management, 12, 188-209.

Duruibe, J.O., Ogwuegbu, M., Egwurugwu, J. (2007). Heavy metal pollution and human biotoxic effects. International Journal of physical sciences, 2, 112-118.

Emamverdian, A., Ding, Y., Mokhberdoran, F., Xie, Y. (2015). Heavy metal stress and some mechanisms of plant defense response. The Scientific World Journal, 2015.

Ernst, W.H. (2005). Phytoextraction of mine wastes-options and impossibilities. Geochemistry, 65, 29-42.

Fan, G., Cang, L., Xu, H., Zhou, D., Zhou, L. (2010). Enhanced electrokinetic remediation of heavy metals-organic pollutants compound contaminated red soils. Journal of Agro-Environment Science, 29, 1098.

Fellet, G., Marchiol, L., Delle Vedove, G., Peressotti, A. (2011). Application of biochar on mine tailings: effects and perspectives for land reclamation. Chemosphere, 83, 1262-1267.

Fergusson, J.E. The heavy elements, chemistry, environmental impact and health effects. Pergamon Press, New Zealand. 1990.

Gajewska, E., Skłodowska, M., Słaba, M., Mazur, J. (2006). Effect of nickel on antioxidative enzyme activities, proline and chlorophyll contents in wheat shoots. Biologia Plantarum, 50, 653-659.

Ghani, A., Ghani, A. (2011). Effect of chromium toxicity on growth, chlorophyll and some mineral nutrients of Brassica juncea L. Egyptian Academic Journal of Biological Sciences, 2, 9-15.

Gil-Loaiza, J., White, S.A., Root, R.A., Solís-Dominguez, F.A., Hammond, C.M., Chorover, J., Maier, R.M. (2016). Phytostabilization of mine tailings using compost-assisted direct planting: Translating greenhouse results to the field. Science of The Total Environment, 565, 451-461. doi:https://doi.org/10.1016/j.scitotenv.2016.04.168.

Gimeno-García, E., Andreu, V., Boluda, R. (1996). Heavy metals incidence in the application of inorganic fertilizers and pesticides to rice farming soils. Environmental pollution, 92, 19-25.

Glick, B.R. (2003). Phytoremediation: synergistic use of plants and bacteria to clean up the environment. Biotechnology advances, 21, 383-393.

Glick, B.R. (2010). Using soil bacteria to facilitate phytoremediation. Biotechnology advances, 28, 367-374.

Goswami, S., Das, S. (2016). Copper phytoremediation potential of Calandula officinalis L. and the role of antioxidant enzymes in metal tolerance. Ecotoxicology and Environmental Safety, 126, 211-218. doi:https://doi.org/10.1016/j.ecoenv.2015.12.030.

Guo, J., Dai, X., Xu, W., Ma, M. (2008). Overexpressing GSH1 and AsPCS1 simultaneously increases the tolerance and accumulation of cadmium and arsenic in Arabidopsis thaliana. Chemosphere, 72, 1020-1026. doi:10.1016/j.chemosphere.2008.04.018.

Gupta, N., Gaurav, S.S., Kumar, A. (2013). Molecular basis of aluminium toxicity in plants: a review. American 
Journal of Plant Sciences, 2013

Hassan, W., Bano, R., Bashir, F., David, J. (2014). Comparative effectiveness of ACC-deaminase and/or nitrogenfixing rhizobacteria in promotion of maize (Zea mays L.) growth under lead pollution. Environmental science and pollution research international, 21, 10983-10996. doi:10.1007/s11356-014-3083-5.

Henson, M.C., Chedrese, P.J. (2004). Endocrine disruption by cadmium, a common environmental toxicant with paradoxical effects on reproduction. Experimental biology and medicine, 229, 383-392.

Hoque, M.A., Burgess, W.G., Shamsudduha, M., Ahmed, K.M. (2011). Delineating low-arsenic groundwater environments in the Bengal Aquifer System, Bangladesh. Applied Geochemistry, 26, 614-623. doi:10.1016/j.apgeochem.2011.01.018.

Hosseini, M., Nabavi, S.M., Parsa, Y. (2013). Bioaccumulation of trace mercury in trophic levels of benthic, benthopelagic, pelagic fish species, and sea birds from Arvand River, Iran. Biological trace element research, 156, 175-180. doi:10.1007/s12011-013-9841-2.

Hossner, L.; Hons, F. Reclamation of mine tailings. In Soil Restoration, Springer: 1992; pp. 311-350.

Huang, S.H., Bing, P., Yang, Z.H., Chai, L.Y., Zhou, L.C. (2009). Chromium accumulation, microorganism population and enzyme activities in soils around chromium-containing slag heap of steel alloy factory. Transactions of Nonferrous Metals Society of China, 19, 241-248.

Hulshof, A.H., Blowes, D.W., Gould, W.D. (2006). Evaluation of in situ layers for treatment of acid mine drainage: a field comparison. Water research, 40, 1816-1826.

Irfan, M., Hayat, S., Ahmad, A., Alyemeni, M.N. (2013). Soil cadmium enrichment: Allocation and plant physiological manifestations. Saudi Journal of Biological Sciences, 20, 1-10.

Israr, M., Sahi, S., Datta, R., Sarkar, D. (2006). Bioaccumulation and physiological effects of mercury in Sesbania drummondii. Chemosphere, 65, 591-598.

Jadia, C.D., Fulekar, M. (2009). Phytoremediation of heavy metals: recent techniques. African journal of biotechnology, 8

Jain, S., Mishra, D., Khare, P., Yadav, V., Deshmukh, Y., Meena, A. (2016). Impact of biochar amendment on enzymatic resilience properties of mine spoils. Science of the Total Environment, 544, 410-421.

Janoš, P., Vávrová, J., Herzogová, L., Pilařová, V. (2010). Effects of inorganic and organic amendments on the mobility (leachability) of heavy metals in contaminated soil: a sequential extraction study. Geoderma, 159, 335-341.

Jegatheesan, V.; Ravishankar, H.; Shu, L.; Wang, J. Application of green and physico-chemical technologies in treating water polluted by heavy metals. In Green Technologies for Sustainable Water Management, 2016; pp. 579-614.

Jeyasingh, J., Philip, L. (2005). Bioremediation of chromium contaminated soil: optimization of operating parameters under laboratory conditions, 118, 113-120.

Karaca, A., Turgay, O.C., Tamer, N. (2006). Effects of a humic deposit (gyttja) on soil chemical and microbiological properties and heavy metal availability. Biology and Fertility of Soils, 42, 585-592.

Karna, R.R., Luxton, T., Bronstein, K.E., Hoponick Redmon, J., Scheckel, K.G. (2017). State of the science review: Potential for beneficial use of waste by-products for in situ remediation of metal-contaminated soil and sediment. Critical Reviews in Environmental Science and Technology, 47, 65-129.

Kidd, P., Barceló, J., Bernal, M.P., Navari-Izzo, F., Poschenrieder, C., Shilev, S., Clemente, R., Monterroso, C. (2009). Trace element behaviour at the root-soil interface: Implications in phytoremediation. Environmental and Experimental Botany, 67, 243-259. doi:https://doi.org/10.1016/j.envexpbot.2009.06.013.

Kim, H.S., Kim, K.R., Yang, J.E., Ok, Y.S., Owens, G., Nehls, T., Wessolek, G., Kim, K.H. (2016). Effect of biochar on reclaimed tidal land soil properties and maize (Zea mays L.) response. Chemosphere, 142. 153159, doi:10.1016/j.chemosphere.2015.06.041.

Kızılkaya, R., Aşkın, T., Bayraklı, B., Sağlam, M. (2004). Microbiological characteristics of soils contaminated with heavy metals. European Journal of Soil Biology, 40, 95-102. doi:https://doi.org/10.1016/j.ejsobi.2004.10.002.

Kou, S., Vincent, G., Gonzalez, E., Pitre, F.E., Labrecque, M., Brereton, N.J.B. (2018). The Response of a 16S Ribosomal RNA Gene Fragment Amplified Community to Lead, Zinc, and Copper Pollution in a Shanghai Field Trial. Frontiers in Microbiology, 9, 366.

Kou, Y., Fu, X., Hou, P., Zhan, Z., Wei, B., Yi, Y. (2008). The Study of Lead Accumulation of Earthworm in Lead Pollution Soil. Environmental Science \& Management, 2008.

Krewski, D., Yokel, R.A., Nieboer, E., Borchelt, D., Cohen, J., Harry, J., Kacew, S., Lindsay, J., Mahfouz, A.M., Rondeau, V. (2007). Human health risk assessment for aluminium, aluminium oxide, and aluminium hydroxide. Journal of Toxicology and Environmental Health, 10, 1-269.

Lee, S.H., Ji, W., Lee, W.S., Koo, N., Koh, I.H., Kim, M.S., Park, J.S. (2014). Influence of amendments and aided phytostabilization on metal availability and mobility in $\mathrm{Pb} / \mathrm{Zn}$ mine tailings. Journal of Environmental Management, 139, 15-21. doi:https://doi.org/10.1016/j.jenvman.2014.02.019. 
Li, J., Zhang, G., Li, Y. (2010). Review on the remediation technologies of POPs. Hebei Environmental Science, $65,1295-1299$.

Li, R., Wang, J.J., Gaston, L.A., Zhou, B., Li, M., Xiao, R., Wang, Q., Zhang, Z., Huang, H., Liang, W. (2018). An overview of carbothermal synthesis of metal-biochar composites for the removal of oxyanion contaminants from aqueous solution. Carbon, 129, 674-687.

Li, X., Huang, L. (2015). Toward a new paradigm for tailings phytostabilization - nature of the substrates, amendment options, and anthropogenic pedogenesis. Critical Reviews in Environmental Science and Technology, 45, 813-839.

Li, Z., Ma, Z., van der Kuijp, T.J., Yuan, Z., Huang, L. (2014). A review of soil heavy metal pollution from mines in China: Pollution and health risk assessment. Science of The Total Environment, 468, 843-853. doi:https://doi.org/10.1016/j.scitotenv.2013.08.090.

Lin, Y., Wang, X., Wang, B., Mohamad, O., Wei, G. (2012). Bioaccumulation characterization of zinc and cadmium by Streptomyces zinciresistens, a novel actinomycete. Ecotoxicology and Environmental Safety, 77, 7-17, doi:10.1016/j.ecoenv.2011.09.016.

Liu K. (2017). The practical signifcance and countermeasures of agricultural waste utilization. Environmental Development, 5,254-6.

Ma, S.C.; Zhang, H.B.; Ma, S.T.; Wang, R.; Wang, G.X.; Shao, Y.; Li, C.X. (2015). Effects of mine wastewater irrigation on activities of soil enzymes and physiological properties, heavy metal uptake and grain yield in winter wheat. Ecotoxicology and Environmental Safety, 113, 483-490. doi:https://doi.org/10.1016/j.ecoenv.2014.12.031.

Ma, Y., Dickinson, N., Wong, M.H. (2006). Beneficial effects of earthworms and arbuscular mycorrhizal fungi on establishment of leguminous trees on $\mathrm{Pb} / \mathrm{Zn}$ mine tailings. Soil Biology and Biochemistry, 38, 1403-1412.

Ma, Y., Rajkumar, M., Freitas, H. (2009). Improvement of plant growth and nickel uptake by nickel resistantplant-growth promoting bacteria. Journal of Hazardous Material, 166. 1154-1161, doi:10.1016/j.jhazmat.2008.12.018.

Mains, D., Craw, D., Rufaut, C., Smith, C. (2006). Phytostabilization of gold mine tailings from New Zealand. Part 2: Experimental evaluation of arsenic mobilization during revegetation. International Journal of Phytoremediation, 8, 163-183.

Manivasagaperumal, R., Balamurugan, S., Thiyagarajan, G., Sekar, J. (2011). Effect of zinc on germination, seedling growth and biochemical content of cluster bean (Cyamopsis tetragonoloba L. Taub). Current Botany, 2011.

Matschullat, J. (2000). Arsenic in the geosphere - A review. Science of the Total Environment, 249, $297-312$

Mazumder, D.G. (2008). Chronic arsenic toxicity \& human health. Indian Journal of Medical Research, 128, 436447.

McGowen, S., Basta, N., Brown, G. (2001). Use of diammonium phosphate to reduce heavy metal solubility and transport in smelter-contaminated soil. Journal of environmental quality, 30, 493-500.

Mench, M., Renella, G., Gelsomino, A., Landi, L., Nannipieri, P. (2006). Biochemical parameters and bacterial species richness in soils contaminated by sludge-borne metals and remediated with inorganic soil amendments. Environmental Pollution, 144, 24-31. doi:10.1016/j.envpol.2006.01.014.

Mendez, M.O., Glenn, E.P., Maier, R.M. (2007). Phytostabilization potential of quailbush for mine tailings. Journal of environmental quality, 36, 245-253.

Mendez, M.O.; Maier, R.M. (2008). Phytostabilization of mine tailings in arid and semiarid environments -An emerging remediation technology. Environmental Health Perspectives, 116, 278-283. doi:10.1289/ehp.10608.

Mirza, N., Pervez, A., Mahmood, Q., Shah, M.M., Shafqat, M.N. (2011). Ecological restoration of arsenic contaminated soil by Arundo donax L. Ecological engineering, 37, 1949-1956.

Monalisa, M., Kumar, P.H. (2013). Effect of ionic and chelate assisted hexavalent chromium on mung bean seedlings (Vigna radiata L. wilczek. var k-851) during seedling growth. Journal of Stress Physiology \& Biochemistry, 9.

Morais, S., Costa, F.G., Pereira, M.D.L. (2012). Heavy metals and human health. Environmental health-emerging issues and practice, 10, 227-246.

Moreno, F.N., Anderson, C.W., Stewart, R.B., Robinson, B.H. (2004). Phytoremediation of mercury-contaminated mine tailings by induced plant-mercury accumulation. Environmental Practice, 6, 165-175.

Mugica-Alvarez, V., Cortés-Jiménez, V., Vaca-Mier, M., Domínguez-Soria, V. (2015). Phytoremediation of mine tailings using Lolium multiflorum. International Journal of Environmental Science and Development, 6, 246.

Murtaza, G., Javed, W., Hussain, A., Qadir, M., Aslam, M. (2017). Soil-applied zinc and copper suppress cadmium uptake and improve the performance of cereals and legumes. International Journal of Phytoremediation, 19, 199-206. doi:10.1080/15226514.2016.1207605.

Nadgorska-Socha, A., Kafel, A., Kandziora-Ciupa, M., Gospodarek, J., Zawisza-Raszka, A. (2013). Accumulation of heavy metals and antioxidant responses in Vicia faba plants grown on monometallic contaminated soil. 
Environmental science and pollution research international, 20, 1124-1134, doi:10.1007/s11356-012-1191-7.

Nagajyoti, P.C. Lee, K.D., Sreekanth, T. (2010). Heavy metals, occurrence and toxicity for plants: a review. Environmental chemistry letters, 8, 199-216.

Odum H.T. Back Ground of Published Studies on Land and Wetland. In: Howard T. Odum (Ed), Heavy Metals in the Environment Using Wetlands for Their Removal, Lewis Publishers, New York USA. 2000, 32.

Ogbomida, E.T., Nakayama, S.M., Bortey-Sam, N., Oroszlany, B., Tongo, I., Enuneku, A.A., Ozekeke, O., Ainerua, M.O., Fasipe, I.P., Ezemonye, L.I. (2018). Accumulation patterns and risk assessment of metals and metalloid in muscle and offal of free-range chickens, cattle and goat in Benin City, Nigeria. Ecotoxicology and environmental safety, 151, 98-108.

Ou-Yang, X., Chen, J., Zhang, X. (2010). Advance in supercritical CO2 fluid extraction of contaminants from soil. Geological Bulletin of China, 29, 1655-1661.

Panou-Filotheou, H., Bosabalidis, A., Karataglis, S. (2001). Effects of copper toxicity on leaves of oregano (Origanum vulgare subsp. hirtum). Annals of Botany, 88, 207-214.

Pardo, T., Bernal, M., Clemente, R. (2014). Efficiency of soil organic and inorganic amendments on the remediation of a contaminated mine soil: I. Effects on trace elements and nutrients solubility and leaching risk. Chemosphere, 107, 121-128.

Pardo, T., Bes, C., Bernal, M.P., Clemente, R. (2016). Alleviation of environmental risks associated with severely contaminated mine tailings using amendments: Modeling of trace element speciation, solubility, and plant accumulation. Environmental toxicology and chemistry, 35, 2874-2884.

Park, J.H., Lamb, D., Paneerselvam, P., Choppala, G., Bolan, N., Chung, J.W. (2011). Role of organic amendments on enhanced bioremediation of heavy metal (loid) contaminated soils. Journal of Hazardous Materials, 185, 549-574.

Pascual, J.A., Hernandez, T., Garcia, C., Ayuso, M. (1998). Enzymatic activities in an arid soil amended with urban organic wastes: Laboratory experiment. Bioresource Technology, 64, 131-138. doi:https://doi.org/10.1016/S0960-8524(97)00171-5.

Pepper, I.L., Zerzghi, H., Bengson, S., Iker, B., Banerjee, M., Brooks, J. (2012). Bacterial populations within copper mine tailings: long - term effects of amendment with Class A biosolids. Journal of applied microbiology, 113, 569-577.

Perronnet, K., Schwartz, C., Gérard, E., Morel, J.L. (2000). Availability of cadmium and zinc accumulated in the leaves of Thlaspi caerulescens incorporated into soil. Plant and Soil, 227, 257-263.

Piha, M., Vallack, H., Reeler, B., Michael, N. (1995). A low input approach to vegetation establishment on mine and coal ash wastes in semi-arid regions. I. Tin mine tailings in Zimbabwe. Journal of Applied Ecology, 372381.

Pulford, I., Watson, C. (2003). Phytoremediation of heavy metal-contaminated land by trees-a review. Environment international, 29, 529-540.

Rahman, H., Sabreen, S., Alam, S., Kawai, S. (2005). Effects of nickel on growth and composition of metal micronutrients in barley plants grown in nutrient solution. Journal of Plant Nutrition, 28, 393-404.

Romero - Puertas, M., Rodríguez-Serrano, M., Corpas, F., Gomez, M.d., Del Rio, L., Sandalio, L. (2004). Cadmium-induced subcellular accumulation of $\mathrm{O} 2 \cdot-$ and $\mathrm{H} 2 \mathrm{O} 2$ in pea leaves. Plant, Cell \& Environment, 27, $1122-1134$.

Ruttens, A., Adriaensen, K., Meers, E., De Vocht, A., Geebelen, W., Carleer, R., Mench, M., Vangronsveld, J. (2010). Long-term sustainability of metal immobilization by soil amendments: cyclonic ashes versus lime addition. Environmental Pollution, 158, 1428-1434.

Salam, M. M. A., Mohsin, M., Pulkkinen, P., Pelkonen, P., Pappinen, A. (2019). Effects of soil amendments on the growth response and phytoextraction capability of a willow variety $(\mathrm{S}$. viminalis $\times \mathrm{S}$. schwerinii $\times \mathrm{S}$. dasyclados) grown in contaminated soils.Ecotoxicology and Environmental Safety, 171, 753-770.

Salt, D.E., Blaylock, M., Kumar, N.P.B.A., Dushenkov, V., Ensley, B.D., Chet, I., Raskin, I. (1995). Phytoremediation: A Novel Strategy for the Removal of Toxic Metals from the Environment Using Plants. BioTechnology, 13, 468-474, doi:10.1038/nbt0595-468.

Sánchez-López, A.S., Carrillo-González, R., González-Chávez, M.d.C.A., Rosas-Saito, G.H., Vangronsveld, J. (2015). Phytobarriers: plants capture particles containing potentially toxic elements originating from mine tailings in semiarid regions. Environmental Pollution, 205, 33-42.

Santibañez, C., de la Fuente, L.M., Bustamante, E., Silva, S., León-Lobos, P., Ginocchio, R. (2012). Potential use of organic-and hard-rock mine wastes on aided phytostabilization of large-scale mine tailings under semiarid Mediterranean climatic conditions: short-term field study. Applied and Environmental Soil Science, 2012.

Satarug, S., Garrett, S.H., Sens, M.A., Sens, D.A. (2010). Cadmium, environmental exposure, and health outcomes. Environmental health perspectives, 118, 182-190.

Schneider, J., Bundschuh, J., Nascimento, C.W.A. (2016). Arbuscular mycorrhizal fungi-assisted phytoremediation of a lead-contaminated site. Science of The Total Environment, 572, 86-97, 
doi:https://doi.org/10.1016/j.scitotenv.2016.07.185.

Seaker, E., Sopper, W. (1988). Municipal sludge for minespoil reclamation: I. Effects on microbial populations and activity. Journal of Environmental Quality, 17, 591-597.

Shaffer, R.E., Cross, J.O., Rose-Pehrsson, S.L., Elam, W.T. (2001). Speciation of Chromium in Simulated Soil Samples Using X-ray Absorption Spectroscopy and Multivariate Calibration. Analytica Chimica Acta, 442 , 295-304.

Shanker, A.K., Cervantes, C., Loza-Tavera, H., Avudainayagam, S. (2005). Chromium toxicity in plants. Environment International, 31, 739-753. doi:10.1016/j.envint.2005.02.003.

Shanley, J.B., Schuster, P.F., Reddy, M.M., Roth, D.A., Taylor, H.E., Aiken, G.R. (2002). Mercury on the move during snowmelt in Vermont. Eos, Transactions American Geophysical Union, 83, 45-48.

Shu, X., Yin, L., Zhang, Q., Wang, W. (2012). Effect of Pb toxicity on leaf growth, antioxidant enzyme activities, and photosynthesis in cuttings and seedlings of Jatropha curcas L. Environmental Science and Pollution Research, 19, 893-902.

Singh, D., Nath, K., Sharma, Y.K. (2007). Response of wheat seed germination and seedling growth under copper stress. Journal of environmental biology, 28, 409-414.

Singh, D., Tiwari, A., Gupta, R. (2012). Phytoremediation of lead from wastewater using aquatic plants. Journal of Agricultural Science and Technology, 8, 1-11.

Soudek, P., Petrová, Š., Vaňková, R., Song, J., Vaněk, T. (2014). Accumulation of heavy metals using Sorghum sp. Chemosphere, 104, 15-24, doi:https://doi.org/10.1016/j.chemosphere.2013.09.079.

Srivastava, P.; Gupta, U. Trace Elements in crop production. Science Pub. Inc. Lebanon, NHO3766 USA. 1996, 366.

Tampouris, S., Papassiopi, N., Paspaliaris, I. (2001). Removal of contaminant metals from fine grained soils, using agglomeration, chloride solutions and pile leaching techniques. Journal of hazardous materials, 84, 297-319.

Tangahu, B.V., Abdullah, S., Rozaimah, S., Basri, H., Idris, M., Anuar, N., Mukhlisin, M. (2011). A review on heavy metals ( $\mathrm{As}, \mathrm{Pb}$ and $\mathrm{Hg}$ ) uptake by plants through phytoremediation. International Journal of Chemical Engineering, 2011.

Thakur, S., Singh, L., Wahid, Z.A., Siddiqui, M.F., Atnaw, S.M., Din, M.F.M. (2016). Plant-driven removal of heavy metals from soil: uptake, translocation, tolerance mechanism, challenges, and future perspectives. Environmental monitoring and assessment, 188, 206.

Thürmer, K., Williams, E., Reutt-Robey, J. (2002). Autocatalytic oxidation of lead crystallite surfaces. Science, 297, 2033-2035.

Tordoff, G., Baker, A., Willis, A. (2000). Current approaches to the revegetation and reclamation of metalliferous mine wastes. Chemosphere, 41, 219-228.

Tsonev, T., Cebola-Lidon, F.J. (2012). Zinc in plants-an overview. Emirates Journal of Food \& Agriculture, 24.

USEPA (United States Environmental Protection Agency). Standards for the use or disposal of sewage sludge. Publication. 2002, 50313.

Vangronsveld, J., Herzig, R., Weyens, N., Boulet, J., Adriaensen, K., Ruttens, A., Thewys, T., Vassilev, A., Meers, E., Nehnevajova, E. (2009). Phytoremediation of contaminated soils and groundwater: lessons from the field. Environmental Science and Pollution Research, 16, 765-794, doi:10.1007/s11356-009-0213-6.

Wahid, A., Ghani, A., Javed, F. (2008). Effect of cadmium on photosynthesis, nutrition and growth of mungbean. Agronomy for sustainable development, 28, 273-280.

Walraven, N., Van Os, B.J.H., Klaver, G.T., Middelburg, J.J., Davies, G.R. (2014). The lead (Pb) isotope signature, behaviour and fate of traffic-related lead pollution in roadside soils in The Netherlands. Science of The Total Environment, 472, 888-900.

Wang, H., Zhao, B., Xu, J., Che, H. (2009). Technology and research progress on remediation of soils contaminated by heavy metals. Environmental Science and Management, 34, 15-20.

Wang, Q., Awasthi, M.K., Ren, X., Zhao, J., Li, R., Shen, F., Zhang, Z. (2017). Effect of calcium bentonite on Zn and $\mathrm{Cu}$ mobility and their accumulation in vegetable growth in soil amended with compost during consecutive planting. Environmental Science and Pollution Research, 24, 15645-15654, doi:10.1007/s11356-017-9212-1.

Wang, Y., Greger, M. (2004). Clonal differences in mercury tolerance, accumulation, and distribution in willow. Journal of Environmental Quality, 33, 1779-1785.

Wang, Y., Pan, F., Wang, G., Zhang, G., Wang, Y., Chen, X., Mao, Z. (2014). Effects of biochar on photosynthesis and antioxidative system of Malus hupehensis Rehd. seedlings under replant conditions. Scientia Horticulturae, 175, 9-15, doi:https://doi.org/10.1016/j.scienta.2014.05.029.

WHO (World Health Organization) International Programme on Chemical Safety, Geneva. Environmental Health Criteria. 1997, 194.

Williams, D., Currey, N. (2002). Engineering closure of an open pit gold operation in a semi-arid climate. International Journal of Surface Mining, Reclamation and Environment, 16, 270-288.

Wong, M.H. (2003). Ecological restoration of mine degraded soils, with emphasis on metal contaminated soils. 
Chemosphere, 50, 775-780.

Xian, Y., Wang, M., Chen, W. (2015). Quantitative assessment on soil enzyme activities of heavy metal contaminated soils with various soil properties. Chemosphere, 139, 604-608. doi:10.1016/j.chemosphere.2014.12.060.

Ye, Z., Shu, W., Zhang, Z., Lan, C., Wong, M.H. (2002). Evaluation of major constraints to revegetation of lead/zinc mine tailings using bioassay techniques. Chemosphere, 47, 1103-1111.

Ye, Z., Wong, J., Wong, M.H. (2000). Vegetation response to lime and manure compost amendments on acid lead/zinc mine tailings: a greenhouse study. Restoration Ecology, 8, 289-295.

Yildirim, D., Sasmaz, A. (2017). Phytoremediation of As, Ag, and Pb in contaminated soils using terrestrial plants grown on Gumuskoy mining area (Kutahya Turkey). Journal of Geochemical Exploration, 182, 228-234. doi:https://doi.org/10.1016/j.gexplo.2016.11.005.

Yin, G., Li, G., Wei, Z., Wan, L., Shui, G., Jing, X. (2011). Stability analysis of a copper tailings dam via laboratory model tests: A Chinese case study. Minerals Engineering, 24, 122-130.

Zhang, W.H., Tyerman, S.D. (1999). Inhibition of water channels by $\mathrm{HgCl} 2$ in intact wheat root cells. Plant physiology, 120, 849-858.

Zhang, Y., Li, Y., Jiang, L., Tian, C., Li, J., Xiao, Z. (2011). Potential of perennial crop on environmental sustainability of agriculture. Procedia Environmental Sciences, 10, 1141-1147.

Zhang, Y., Sheng, J., Lu, Q. (2004). Review on the soil remediation technologies. Gansu Agricultural Science and Technology, 10, 36-38.

Zhou, D., Hao, X., Xue, Y., Cang, L., Wang, Y., Chen, H. (2004). Advances in remediation technologies of contaminated soils. Ecology and Environmental Sciences, 13, 234-242.

Zubair, M., Shakir, M., Ali, Q., Rani, N., Fatima, N., Farooq, S., Shafiq, S., Kanwal, N., Ali, F., Nasir, I.A. (2016). Rhizobacteria and phytoremediation of heavy metals. Environmental Technology Reviews, 5, 112-119. 